Diajukan: 05-11-2018 | Revisi: 17-01-2019 | Diterima: 24-01-2019

\title{
Pelatihan Ekonomi dan Keuangan Syariah dalam Rangka Pembentukan Baitul Mal wat Tamwil
}

\author{
Sri Herianingrum ${ }^{1}$, Eko Fajar Cahyono ${ }^{2}$, Lina Nugraha Rani ${ }^{3}$, Sylva Alif Rusmita ${ }^{4}$ \\ Universitas Airlangga Surabaya ${ }^{1234}$
}

\begin{abstract}
The background of this activity was to fulfill the aspirations of the Muslims of Bandar Kidul village, Mojoroto Subdistrict, Kediri City to carry out economic activities following Islamic rules and the potential capabilities and skills possessed by management and members of the Fascho Cooperation to manage Islamic microfinance institutions such as Baitul Wattamwil. The purpose of this community service activity is to provide understanding, knowledge, and skills to the management and members of the Fascho Cooperation who are engaged in Mojoroto Subdistrict, Kediri City about Islamic economics and Islamic Finance. The activity took place in May 2018, and the actions were in the form of workshop and socialization about Islamic economics and Islamic finance. The article is expected to be a provision for administrators and members to establish Baitul mal wattamwil. The results of the activities were in the form of increased awareness of the community around the location of the community service and the increased knowledge and skills of the members and administrators of the Fascho Cooperation so that they were better prepared to establish the BMT.
\end{abstract}

Keywords: Baitulmalwattamwil; syari'ah cooperation; islamic economics; islamic finance; workshop; socialization

\begin{abstract}
Abstrak
Latar belakang kegiatan ini adalah untuk memenuhi aspirasi umat Islam di desa Bandar Kidul, Kecamatan Mojoroto, Kota Kediri untuk melaksanakan kegiatan ekonomi mengikuti aturan Islam dan potensi kemampuan dan keterampilan yang dimiliki oleh manajemen dan anggota koperasi Fascho untuk mengelola keuangan mikro Islam lembaga seperti Baitul Wattamwil. Tujuan dari kegiatan pengabdian masyarakat ini adalah untuk memberikan pemahaman, pengetahuan, dan keterampilan kepada manajemen dan anggota koperasi Fascho yang bergerak di Kecamatan Mojoroto, Kota Kediri tentang ekonomi Islam dan Keuangan Islam. Kegiatan tersebut berlangsung pada Mei 2018, dan aksinya dalam bentuk lokakarya dan sosialisasi tentang ekonomi Islam dan keuangan Islam. Artikel ini diharapkan menjadi ketentuan bagi administrator dan anggota untuk mendirikan Baitul mal wattamwil. Hasil kegiatan adalah dalam bentuk peningkatan kesadaran masyarakat di sekitar lokasi pelayanan masyarakat dan peningkatan pengetahuan dan keterampilan anggota dan administrator Koperasi Fascho sehingga mereka lebih siap untuk mendirikan BMT.
\end{abstract}

Kata Kunci: Baitul maal wat tamwil; koperasi syariah; ekonomi islam; keuangan islam; workshop; sosialisasi

\section{Pendahuluan}

Salah satu kunci penting dalam pembangunan ekonomi Negara adalah adanya pertumbuhan inklsuif (Rofik, Lestari, \& Septianda, 2018).Pertumbuhan inklusif adalah keadaaan dimana pertumbuhan ekonomi dinikmati semua kalangan termasuk kaum miskin dan kaum papa. Pertumbuhan ekonomi inklusif mendorong perluasan ekonomi perluasan akses perekonomian, kondisi ini menciptakan kemerataan. Pertumbuhan inklusif adalah sebuah model yang mendorong perlindungan pasar, dan transisi tenaga kerja yang sangat dibutuhkan untuk kesuksesan strategi pertumbuhan (Sanjaya, 2014). Faktor kunci terjadinya pertumbuhan inklusif adalah dengan adanya inklusi keuangan. Inklusi keuangan adalah didefinisikan sebagai penyediaan akses bagi masyarakat termarginalkan (masyarakat miskin) untuk dapat memiliki dan menggunakan layanan sistem keuangan. Sanjaya (2014) mengutip Sarma (2012) terdapat tiga dimensi yang harus diperhatikan dalam inklusi keuangan yaitu aksesibilitas, ketersediaan, dan penggunaan layanan sistem keuangan.

Praktik penegakan inklusi keuangan telah dilakukan oleh koperasi Fascho. Koperasi ini merupakan lembaga keuangan mikro yang melakukan fungsi intermediasi keuangan di kalangan masyarakat bawah. Sitio (2001) menyatakan bahwa koperasi dibentuk atas dasar persamaan kepentingan anggota dan tujuan dibentuk adalah untuk mengurusi kepentingan anggota. Koperasi digunakan untuk menciptakan keuntungan timbal balik antara koperasi dan anggota. Sitio (2001) mengutip konsep koperasi menurut sosialisasi yang menyatakan bahwa koperasi bertujuan untuk memberikan kepemilikan kolektif atau kepemelikan bersama untuk tujuan sosial politik.

\footnotetext{
1 Herianingrum@feb.unair.ac.id

2 ekofajarc@feb.unair.ac.id
} 
Penduduk desa Bandar Kidul Kecamatan Mojoroto Kota Kediri adalah bagian dari masyarakat Indonesia. Untuk mewujudkan adanya pertumbuhan inklusif dan inklusi keuangan perlu campur tangan dari berbagai pihak dan utamanya adalah akademisi. Seperti yang tertera pada tri darma perguruan tinggi, Universitas Airlangga mempunyai kewajiban untuk membantu masyarakat dalam mencari solusi dari masalah yang dihadapi oleh masyarakat.

Profil penduduk desa Bandar Kidul Kidul Kecamatan Mojoroto Kota Kediri dapat diruriakan sebagai berikut, merupakan desa yang sebagian besar penduduknya bermata pencaharian sebagai pedagang, guru, pegawai negeri, dan ustadz serta ustadzah. Sementara itu para ibu di Desa Bandar Kidul, sebagian besar merupakan ibu rumah tangga biasa. Desa Bandar Kidul, Kecamatan Mojoroto memiliki penduduk kurang lebih 30.000 warga, di mana sekitar $51 \%$ penduduknya perempuan dan $49 \%$ adalah penduduk lakilaki. Sekitar $60 \%$ penduduknya berprofesi dibidang perdagangan, sisanya berprofesi di bidang jasa baik sebagai guru, ustadz, ustadzah, perbankan, dan jasa lainnya. Sebagian kecil penduduk yang bergerak dibidang perdagangan adalah para pedagang kecil, yang barang dagangannya memiliki nilai aset kurang dari Rp 500.000,-. Dalam menjaga kelangsungan usahanya ternyata para pedagang kecil ini masih sangat membutuhkan lembaga keuangan mikro, antara lain koperasi.Kebutuhan koperasi dipenuhi oleh keberadaan koperasi Faskho. Jumlah anggota koperasi Fascho 300 orang lebih, terdiri dari berbagai profesi, termasuk para pedagang kecil. Pinjaman yang disalurkan paling rendah adalah $\mathrm{Rp} 500.000,-$ dan yang tertinggi sebesar Rp20.000.000,-. Pinjaman rendah atau Rp 500.000,- diangsur 5 (lima) kali, sedangkan pinjaman tinggi atau Rp 20.000.000,- diangsur 50 (lima puluh ) kali.

Koperasi Fascho didirikan oleh jama'ah pengajian di Bandar Kidul, oleh salah satu tokoh koperasi di desa tersebut yaitu alm. Bapak Muchlish, guru SMA di Kediri. Koperasi Faskho terletak di Jl. KH. Wachid Hasyim No. 180 Desa Bandar Kidul, saat ini diketuai oleh H. Djazuli. Beliau ingin mengalikan koperasi nya menjadi BMT (Baitul Maal Wat Tamwil), karena ingin mengikuti prinsip Islam yang dinilai lebih adil. Pihak pengurus menyadari bahwa dengan sistem ekonomi syariah maka segala transaksi menjadi halal karena menggunakan system jual beli dan tidak ada utang piutang yang mengandung Riba. Oleh karena itu, pendiri dari koperasi tersebut ingin jika koperasi nya dialihkan menjadi koperasi yang berbasiskan syariah atau bisa disebut dengan BMT (Baitul Maal Wat Tamwil).

Faktor utama keberhasilan pembangunan adalah adanya faktor nonfisik. Faktor nonfisik tersebut misalnya adalah tata nilai dan norma yang dipegang teguh oleh masyarakat (Todaro, 2003). Sebagian masyarakat Indonesia melakukan suatu tindakan atau aksi berdasarkan nilai yang diyakininya benar. Pengingkaran terhadap nilai nilai terhadap proses pemberdayaan masyarakat akan mengakibatkan proses pemberdayaan masyarakat (Widjayanti, 2011). Dengan demikian aspirasi untuk mengubah dari koperasi menjadi Biatulmalwatamwil perlu dilakukan karena adanya kesesuain antara program pemberdayaan dengan nilai nilai yang dianut masyarakat setempat yaitu ajaran agama Islam.

Dalam pelaksanaan perubahan koperasi menjadi BMT atau Koperasi Syariah, pihak pengelola dan pengurus mengalami kendala karena kurangnya wawasan mengenai Koperasi Syariah atau BMT, baik dari segi tata cara pendirian BMT, bagaimana prosedur mengalihkan koperasi konvensional menjadi BMT, syarat-syarat pendirian BMT serta kegiatan usaha yang akan dilakukan jika sudah beralih menjadi BMT, dan lain-lain.

Berdasarkan hasil identifikasi permasalahan, maka terdapat beberapa masalah prioritas yang harus segera diatasi, terkait masih sangat rendahnya pengetahuan pengurus dan anggota koperasi Fascho tentang koperasi nerdasarkan prinsip Islam (BMT). Berdasarkan hasil wawancara dan pengamatan di lapangan, maka perlu dilakukan usaha-usaha yang perlu dilakukan dalam upaya menjaga keberlangsungan koperasi atau BMT di Kediri antara lain: 1) terbatasnya pemahaman pengurus koperasi tentang pengelolaan berdasarkan prinsip syariah (BMT). Hal ini perlu segera diwujudkan dengan melakukan berbagai pelatihan; 2) jumlah anggota yang relatif banyak, dan tingginya kebutuhan pinjaman kepada koperasi mengidikasikan perlu ada sosialisasi tentang BMT (koperasi syariah) kepada pengurus serta anggota koperasi; 3) pentingmya menjaga proses kesyariahan koperasi, maka perlu pendampingan dari dosen dan mahasiswa agar koperasi Faskho segera mampu mengopersionalkan sebagai BMT.

\section{Materi dan Metode Pelaksanaan}

Pelaksanaan pelatihan dilaksanakan pada Sabtu, 31 Mei 2018, pukul 08.00 hingga pukul 15.30, jumlah Peserta: 35 orang, bertempat di Masjid Bandar Kidul, Desa Bandar Kidul, Kecamatan Mojoroto, Kota Kediri dengan materi sebagai berikut:

1) Profil, Visi, Misi Koperasi: Ketua Koperasi Fascho, Drs. H. Djazuli

2) Pengantar Ekonomi Islam,Prinsip dan Sistem: Dr Hj Sri Herianingrum ,SE,MSi

3) Pengantar Keuangan Islam, Prinsip, Sistem dan Akad Fikih Muamalah: Lina Nugraha Rani,SE,MSi

4) Tanya jawab penggalian masalah 
5) Moderator: Khoirul Jadid

6) Pemimpin Acara: Eko Fajar Cahyono,SE,ME

7) Konsumsi, training kit, absensi, dokumentasi: Sylva Alif Rusmita,SE,CIFP dan dibantu 4 orang mahasiswa

\section{Organisasi Pelaksana}

1) Narasumber $1 \&$ Koordinator: Dr Hj Sri Herianingrum dan Lina Nugraharani,SE,MSi

2) Pemimpin Acara \& PJ Pelaksanaan Workshop: Eko Fajar Cahyono,SE,ME

3) PJ Kesekretariatan \& koordinator mahasiswa: Sylva Alif Rusmita,SE,CIFP

4) Dokumentasi, Perlengkapan \& Konsumsi: Mahasiswa 4 orang.

\section{Hasil dan Pembahasan}

Secara umum, pelatihan ini didasarkan pada profil BMT yang kemukakan Soemitra (2017). BMT ditujukan untuk meningkatkan kualitas usaha ekonomi untuk kesejahteraan anggota pada khususnya dan masyarakat pada umumnya. BMT juga harus memiliki usaha bisnis yang bersifat mandiri, ditumbuhkembangkan dengan swadaya dan dikelola secara professional untuk kesejahteraan anggota dan masyarakat lingkungannya. Somitra juga menekankan bahwa BMT harus menjadi lembaga keuangan yang mandiri, sehat dan kuat, sehingga mampu berperan menjadi wakil pengabdi Allah memakmurkan kehidupan anggota pada khususnya dan umat manusia pada umumnya. Berkenaan dengan pentingnya Visi dan Misi BMT idealnya mampu mewujudkan gerakan pembebasan anggota dan masyarakat dari belenggu rentenir, jerat kemiskinan dan ekonommi ribawi, gerakan pemberdayaan meningkatkan kapasitas dalam kegiatan ekonomi riil dan kelembagaannya menuju tatanan perekonomian yang makmur dan maju.

Pandangan Soemitra mengenai BMT kemudian diterjemahkan pada pelatihan yang dilakukan, pada pelatihan tersebut juga ditekankan mengenai tahapan-tahapan pendirian BMT sebagai berikut:

1. Perlu adanya pemrakarsa, motivator yang telah mengetahui BMT. Pemrakarsa mencoba meluaskan jaringan para sahabat dengan menjealaskan BMT dan peranannya dalam mengangkat harkat dan martabat rakyat. Jika dukungan cukup ada, maka perlu berkonsultasi dengan tokoh-tokoh masyarkat setempat yang berpengaruh, baik yang formal maupun yang informal

2. Diantara pemrakarsa membentuk Panitia Penyiapan Pendirian BMT (P3B) di lokasi jamaah masjid, pesantren, desa miskin, kelurahan, kecamatan, atau lainnya. Jika dalam satu kecamatan terdapat beberapa P3B, maka P3B kecamatan menjadi coordinator $\mathrm{P} 3 \mathrm{~B}$ yang ada

3. P3B mencari modal awal atau modal perangsang sebesar Rp. 10.000.000,- sampai dengan Rp. 30.000.000,- agar BMT memulai operasi dengan syarat modal itu. Modal awal ini dapat berasal dari perorangan, lembaga, yayasan, BAZIS, Pemda dan sumber lainnya.

4. P3B bias mencari modal-modal pendiri (Simpanan Pokok Khusus/SPK semacam saham) dari sekitar 20-44 orang di kawasan tersebut untuk mendapatkan dana urunan. Untuk kawasan perkotaan mencapai jumlah Rp. 20.000.000 sampai Rp. 35.000.000. Sedangkan untuk kawasa pedesaan SPK antara Rp. 10.000.000 sampai Rp. 20.000.000. Masing-masing para pendiri perlu membuat komitmen tentang peranan masing-masing

5. Jika calon pemodal-pemodal pendiri telah ada, maka dipilih pengurus yang ramping ( 3 orang, maksimal 5 orang) yang akan mewakili pendiri dalam mengarahkan kebijakan BMT. Pengurus mewakili para pemilik modal BMT.

6. P3B atau pengurus jika telah ada mencari dan memilih calon pengelola BMT.

7. Mempersiapkan legalitas hukum untuk usaha sebagai :

a. KSM/LKM dengan mengirim surat ke PINBUK

b. Koperasi Simpan Pinjam (KSP) Syariah atau Koperasi Serba Usaha (KSU) unit syariah dengan menghubungi kepala kantor/dinas/badan koperasi dengan pembinaan pengusaha kecil di Ibukota, Kabupaten/Kota.

8. Melatih calon pengelola sebaiknya juga diikuti oleh satu orang pengurus dengan menghubungi kantor PINBUK terdekat.

9. Melaksanakan persiapan-persiapan sarana kantor dan berkas administrasi yang diperlukan

10. Melaksanakan bisnis operasi BMT

Dengan jumlah penduduk Muslim terbesar di dunia, Indonesia telah menjadi negara dengan Islamic Micro Finance yang besar di dunia. Sampai saat ini tidak ada data akurat mengenai jumlah dan pesebaran BMT di Indonesia. Sakti (2013) merujuk data BMT link memperkirakan jumlah BMT tahun 2006 sebanyak 3.200 meliputi jumlah nasabah sebanyak 3 juta orang, data menunjukan sampai tahun 2010 tumbuh menjadi perkiraan 5.200 BMT dalam rangka menjangkau nasabah 10 juta orang. Sakti (2013) mengutip pernyataan Muhammad Kholim (2004) menyebutkan bahwa tiga daerah dengan jumlah BMT 
terbesar di Indonesia adalah provinsi Jawa Barat dengan 637 BMT (433 BMT yang kegiatanya dilaporkan ke PINBUK), Jawa Timur dengan 600 BMT (519 BMT yang terlapor kegiatannya) dan Jawa Tengah menduduki urutan ketiga dengan 513 BMT (447 BMT yang diporkan ke PINBUK).

\section{Kesimpulan dan Saran}

Prinsip prinsip dan sistem ekonomi Islam yang menitikberatkan kepada keadilan dan kejujuran, dapat diterapkan pada calon BMT Fascho, Mojoroto, Kota Kediri. Strategi BMT menggunakan akad-akad syariah, seperti musyarakah dan mudharabah lebih efisien di tengah kendala keterbatasan dana, kebutuhan dan berbagai masalah anggota koperasi Fashco Mojoroto Kota Kediri, seperti perawatan tenda penjualan, pembelian sembako bersama supaya harga lebih rendah dengan mendapat discount, dan kebutuhan anggota keluarga Koperasi Fascho, seperti sakit, biaya masuk sekolah dan lain-lain. Semua bentuk-bentuk akad berbasis syariah dapat diaplikasikan guna mengatasi permasalahan produksi, permodalan, pemasaran dan kebutuhan anggota koperasi Fascho, Mojoroto Kediri melalui kerja sama dalam sebuah koperasi

\section{Referensi}

Rofik, M., Lestari, N. P., \& Septianda, R. (2018). Pertumbuhan ekonomi, upah minimum dan tingkat pengangguran di Kalimantan Barat, 03(02), 45-52.

Sakti, A. (2013). Pemetaan kondisi dan potensi bmt: kemitraan dalam rangka memperluas pasar \& jangkauan pelayanan bank syariah kepada usaha mikro. Al-Muzara'ah, 1(1), 1-18.

Sanjaya, I. (2014). Inklusi keuangan dan pertumbuhan inklusif sebagai strategi pengentasan kemiskinan di Indonesia.

Sitio, A. (2001). Koperasi: teori dan praktek: Erlangga.

Soemitra, A. (2017). Bank \& lembaga keuangan syariah: Prenada Media.

Todaro, M.P. dan S.C. Smith. (2003). Pembangunan ekonomi dunia ketiga jilid I edisi kedelapan. Jakarta: Erlangga

Widjajanti, K. (2011). Model pemberdayaan masyarakat. 